\title{
A Statistical Assessment of Liquidity Management and Profitability in a Cross Section of Deposit Money Banks in Nigeria using Panel Analysis
}

\author{
Ibrahim Shaibu, Ph.D. \\ Department of Business Administration, \\ University of Benin, Benin City. \\ Professor Chinwuba Okafor, Ph.D. \\ Department of Accounting, \\ University of Benin, Benin City.
}

\begin{abstract}
The objective of this study was to examine the relationship between liquidity and profitability of deposit money banks in Nigeria using panel approach. The study made use of a sample size of ten deposit money banks in Nigeria. Data used for the study were sourced from the annual reports of the sampled firms and the statistical bulletin of the Central Bank of Nigeria ranging from 2006 to 2016. The liquidity indicators that were used were current ratio (current assets to current liabilities) (CRT), cash to total asset ratio (CTA), cash to total deposit ratio (CTD), liquid asset to total assets ratio (LATA), and loan to total deposit ratio (LTD), while return on assets (ROA) was used as proxy for profitability. A panel data regression model was specified and estimated. The empirical results showed that there was a positive and statistically significant relationship between cash to total asset (CTA) ratio and liquid asset to total assets (LATA) with profitability, and there was a negative but statistically significant relationship between cash to total deposit (CTD) ratio and profitability. It was also revealed that current ratio (CRT) and loan to total deposit (LTD) had a positive but statistically not significant relationship with profitability. It was recommended that the deposit money banks should not only focus on the profit maximization perception but also embrace methods that will certify effective and efficient liquidity management since its survival and sustainability depends on effective liquidity management and profitability. This will help to reduce the negative effects of the incidence of deficient and excessive liquidity.
\end{abstract}

Keywords: Liquidity, profitability, return on assets, panel approach, cash to total assets, cash to total deposits, Liquid assets to total deposits, Current assets, Loan to total deposits.

\section{INTRODUCTION}

Nations across the world have adopted and are still adopting economic policies to regulate their economies in order to prevent what happened during the great depression (Oriavwote \& Eshenake, 2015). Financial institutions play an important role in the design and evaluation of current and future macroeconomic policies aimed at achieving economic stability (Arize, 2012). The financial institutions such as banks are seen as the pillars of the financial system, providing efficient devices for easy deployment of resources and directing them effectively and efficiently for productive uses (Wilner, 2000). In view of the above, reason liquidity issues have been a concern of all the nations across the world, because no sector in any economy can survive without adequate funds (Ismail, 2016).

The attempts by bank management to increase profitability or returns may negatively affect liquidity which might not be favourable to the bank as it could result in loss of goodwill, patronage as well as reduction in banks credit standard and at the extreme, it could lead to 
force liquidation of the banks' assets. However, maintaining excess liquidity to meet up with customers' withdrawal obligations may also affect profitability. Therefore liquidity should be managed to obtain optimum possible level. However, this optimum level should be able to meet short-term obligations as they fall due.

The hitches of inefficiency in the management of banks liquidity in Nigeria became obvious during the distress and liquidation eras in the late 1980s as well as early 1990s. The adverse effects of the banking system liquidity problem in these periods remained up to the recapitalization era in 2005 in which banks were mandated to increase their capital base from N2 billion to N25 billion. It was believed this directive by the Central Bank of Nigeria (CBN) would rectify and stabilize the banks liquidity challenges that were predominant in the economy (Fadare, 2011).

The recent uproar in the global economic system has showed some short comings in liquidity management of the financial sector in Nigeria. During the last banking crisis in 2009 many deposit money banks ran out of liquidity while some raised funds at a high discount in order to meet up with customers' demand for exigent cash. Many financial organizations had to revisit their corporate governance policies to absorb market and liquidity risk exposures. Foreign exchange rate, commodity prices, interest rate, equity prices, and credit spread displayed adverse effect on banks performance in general and their profitability in particular as networth and returns on investment of their businesses fell tremendously. Some banks hardly could meet their financial obligations as and when due or when they did, they discharged them at exorbitant cost. These affected the banks' ability in stimulating productive economy.

The Central Bank of Nigeria (CBN) over the past years, particularly since 1958, has formulated policy thrusts to restore the Nigerian financial system for sustainable economic growth. These policies which came in the form of merger and acquisition, consolidation, re-capitalization, among others were all aimed at revamping the financial system with little or no effort on the efficiency of the management of liquidity. For example, the incident of 1990s which brought about the unprecedented level of distress revealed by high rate of insolvency, liquidity problem, large volume of non-performing loans, and failure in meeting depositors and interbank responsibilities, all necessitated the innovations in the banking industry in 1986. The 2008 global financial crisis also had its bit on the confidence and the financial conditions. In what was seen as a stimulated repositioning of banks against lack of liquidity the Central Bank of Nigeria came on a rescue mission in 2009 to save five illiquid banks by by injecting the sum of $\mathrm{N} 620$ billion into the sector in 2009 as a rescue mission to save the five banks that were operating on a negative shareholders' funds. Government directive to withdraw the deposits of governments and other public agencies in 1989 from deposit money banks coupled with the directive on treasury single account (TSA) by the Federal government in 2015 are all examples of reforms that could reposition the liquidity in the banking industry in Nigeria.

These innovations and other banking reforms in Nigeria have not produced sufficient results in stabilizing the banking sector. This is evidenced in the undulating exchange rates, high interest rates, and other liquidity challenges in the banking sector. One major reason that has been adduced for the failure of most policy measures in Nigeria is the relatively weak scientific efforts at explaining the dynamics of the policy objective. As a result, policy making has relied upon decisions that are not anchored on scientific models that track major economic indices (Adenikinju, Busari, \& Olofin, 2009). 
Against this background, the aim of this study was to empirically develop a model that explained the relationship between some selected liquidity and profitability indicators in Nigerian deposit money banks between 2006 and 2016. Thus, this study did not only investigate the effect of liquidity levels on profitability of commercial banks in Nigeria, it also extended previous works to cover more temporal and cross sectional dimension on the liquidity and profitability of banks in Nigeria. The idea was to develop and estimate a scientific model that would ensure that decision making with respect to liquidity and profitability are anchored on banks' major economic indices.

\section{REVIEW OF LITERATURE}

Deposit money banks are like every other business organization with the purpose of profit making. The banks' profits are mainly from interest on their assets earnings, such as their investment and loans. For this reason, the banks need to ensure healthy liquidity position while maximizing profit at the same time. A firm can be regarded as liquid if it can easily convert its assets to cash without much delays and inconveniences.

There are several sources from which bank gets their liquidity. These include balances held with Central Bank, vault cash, balances with offices outside Nigeria, inter-bank placement, money at call in Nigeria, discount houses placement, investment in stabilizations securities, treasuring bills and certificates, commercial papers, and bankers acceptances.

Bank's liquidity in simple terms is the bank's ability to sufficiently maintain funds to meet its financial obligations such as cheques, cash, legitimate new loans and other withdrawal obligations while maintaining the statutory reserve requirements. The best capital structure is obtained by having in mind the financial requirements of both the short-term and long term periods. According to Biety (2003) liquidity is the ease and speed with which an asset is sold and still realizes fair price. Liquidity therefore is seen as the entries and leakages of cash through the firm as sales payment, product procurement, and the processes of collection taking place over time, by which asset can be converted into cash without a substantial loss of principal liquid asset. It is a relationship between the time frame it requires to make sales and the discount from fair market price of an investment asset. Therefore, an enterprise should make sure that it does not suffer from inadequate liquidity and at the same time, does not have surplus liquidity. The inability to meet financial obligations as a result of insufficient liquidity can result in loss of creditors' confidence and poor credit worthiness. On the other hand, a high percentage of liquidity can also result in cash being idle (CBN, 2015).

The concept of liquidity management involves the efficient and effective planning and organizing of the assets of banks that will maximize its profitability and liquidity at the lowest cost possible. Management of liquidity is the calculated supply or withdrawal the amount of liquidity consistent with preferred level of short-term reserve money without altering the ability to make profit and operations of the bank from the market circulation (Aghada \& Osuji, 2013). Generally, liquidity adequacy plays very important role in the successful running of all business organizations.

Liquidity could be Central Bank liquidity, funding liquidity, or market liquidity. Central Bank liquidity is seen as the flow of liquidity to the financial sector from the Central Bank. According to the International Monetary Fund (IMF), funding liquidity is the ability to timely meet payments as they fall due. Market liquidity is the capability of an asset to be traded within the shortest possible time, with little or no significant effect on the price and at lowest possible cost (Fernandez, 1999). 
Though the issue of liquidity is vital to other businesses, it is of most significant to the banking sector. Thus banks ensure the availability of cash and other financial assets to meet customers demand of liquidity (Aghada \& Osuji, 2013). As a means to effectively manage the liquidity positions of banks in Nigeria, the Central Bank mandatorily requires the banks to comply with the Cash Reserve Requirement policy (CRR).

Performance is the end result of activity. Organizations can generally use objective and subjective measures to assess their performance. Objective measures mostly encompass comparing corporate performance with financial measures, while subjective measures refer to personal perceptions about business performance (Shaibu, 2010). Which measures to select to assess performance depends on the organizational unit to be appraised and the objectives to be achieved. The objectives of profitability, market share, and cost reduction, among others should certainly be used to measure corporate performance. Some measures, such as return on investment (ROI) or return on assets (ROA), are appropriate for evaluating a company's ability to achieve a profitability objective.

Traditionally, business performance has been assessed by financial measures like, return on assets employed (or return on investment), return on sales, growth in revenues, sales revenue, return on equity, earnings per share, net profit margin, stock returns and economic embedded value, market share (Shaibu, 2010). The most commonly used traditional measure of corporate performance (in terms of profit) is return on investment (ROI). It is simply the result of dividing net income before taxes by the total amount invested in the company (typically measured by total assets).

The use and reliance on financial measures of business performance, such as return on investment, has been supported by various authors. For instance, Brancato (1995) has stated that using return on investment (ROI) has several advantages. The return on investment (ROI) is a single, comprehensive number that includes all revenues, costs, and expenses; it can be used to evaluate the performance of general manager of a division or SBU; it can be compared across companies to see which firms are performing better; it is subjected to internal controls which make them reliable; they are also reported externally and hence are subject to public scrutiny; and it provides an incentive to use current assets efficiently and to acquire new assets only when they would increase profits significantly.

Many theories abound on the relationship between profitability and liquidity of banks. The underlying question which these theories intend to answer is the effect of liquidity on the profitability of banks. It was noted by Osborne, Fuertes, and Milne (2012) that having high liquidity ratio is usually at the expense of the bank which implies that profitability is reduced with higher liquidity. Going by the theory of the trade-off however, higher liquidity reduces the risk of banks and save the premium that would have been used in case of bankruptcy situation. On the average, according to corporate financial conventional theory, banks will prefer to hold on optimal liquidity which can trade off returns. However, because of the monetary authorities' requirement on deposit reserve, it forces the banks to hold more liquidity than they would have ordinarily held. In addition, as it is expected that banks optimal level of liquidity may fluctuate, depending on the business cycle which is likely to increase when the expected cost of distress is high, therefore a higher cyclical relationship is expected between liquidity and profitability, which is expected to be more positive during distress period as the profitability of banks increased as they increase their liquidity in the distress period. Therefore, there may be a positive or negative relationship between liquidity and profitability in short run, this will depend on liquidity level of the bank, whether it is below or above optimal at that period. 
It was asserted by Flannery and Regan (2008) that there might be no short run relationship in the first place if banks successfully attain optimal level of liquidity since it has been implied by the conditions of the first order standards that there will be no effect on profitability by any change that occurs in liquidity. However the regulatory requirement on liquidity in the longrun may still be binding. It therefore implies that having higher liquidity can only reduce profitability if the banks go above their optimal level of liquidity either due to unexpected shock or requirements of regulatory authorities. In line with the above, it was opined by Osborne, Fuertes, and Milne (2012) that the optimal level of liquidity of banks' rises during the banking sector distress periods because in such periods it is expected that the bankruptcy cost should rise. It is therefore self-evidence that the average relationship that will exist between liquidity and profitability will be cyclical across banks. This results because banks go below their optimal level of liquidity in an environment that is distressed, whereas, it is possible for the banks to meet or not to meet their highest level of capital when the environment is normal. In either case, the relationship that will exist between liquidity and profitability would be zero approximately, in such case, the banks may reduce their liquidity to achieve a higher profitability level.

It is easier for a bank with a higher level of liquidity to survive and be more profitable in the future than a bank with a less level of liquidity. According to Allen and Marguez (2011), this may bring about a high voluntary liquidity buffer in the open market because a more effective way to guarantee the banks solvency is the high liquidity level of the bank. This will therefore enable the bank to lend the surplus to the investing public which will also, in turn, bring about a higher level of profitability.

Bordeleau and Graham (2010) investigated the impact of holding liquid assets on the profitability of the Canadian and the United States (US) banks using panel data with ordinary least square regression method. They found that banks that hold liquid assets improve their profitability. However, all things being equal, there is a level that further liquid assets holding minimize the profitability of the banks.

Goddard, Molyneux, and Wilson (2004) investigated the United States banks profitability during the 1990s, using the dynamic and pooled panel models. The determinants for the profitability model include diversification, size, dynamic effects and ownership type. The researchers found a weak relationship between the regressors and profitability.

Eljelly (2004) studied the relationship between liquidity and profitability in Saudi Arabia. This relationship was measured using cash gap and current ratio on a cross section of different industries. By using the regression and correlation analysis, it was found that there exist an inverse relationship between liquidity and profitability ratio in Saudi Arabia.

Naceur (2003) investigated what determines the profitability of the Tunisia banking sector, using a sample size of ten banks for the time frame of 20 years that is from $1980-2000$. Using the regression analysis, he found that banks that have huge capital as well as overheads have the tendency to have large net interest margin as well as profitability. The study further emphasized those determinants like bank size has a negative relationship with profitability, while loans have positive relationship with banks profitability.

Some studies have been conducted on the relationship between liquidity and profitability in Nigerian banks (Adeyinka, 2013; Aghada \& Osuji, 2013; Bassey, 2016; Ibe, 2013). Adeyinka (2013) examined the efficacy of capital adequacy of deposit money banks profitability in Nigeria from 2006 to 2010. A statistically significant relationship was found to exist between 
liquidity adequacy and banks profitability in Nigeria. The implication of the result is that the profitability of deposit money banks in Nigeria is majorly determined by liquidity adequacy. It was showed that liquidity and profitability are bank risk management efficiency indicators.

Aghada and Osuji (2013) conducted a study on the effect of liquidity management on the performance of the Nigerian banks. The study employed return on capital employed (ROCE) and profitability as proxies for bank performance. Using regression and correlation analysis, they found that the relationship that exists between banking performance and efficient management of liquidity was statistically significant.

Ibe (2013) examined the effect of liquidity management on the profitability of banks in Nigeria. The study made use of a sample size of three (3) banks in Nigeria to represent the banking industry. The study made use of bank balances, cash and short term fund treasury bills and certificate as proxies for liquidity, while profitability was proxied by profit after tax (PAT). Using the ordinary least squares regression, the study showed that liquidity management has a critical problem in the banking industry in Nigeria.

Bassey and Moses (2015) investigated the tradeoff between liquidity and profitability in the Nigerian banks from 2010 to 2012. Using the ordinary least squares (OLS) technique for the empirical analysis, they found a significant relationship between liquidity and profitability of banks in Nigeria when profitability was proxied by return on assets.

Bassey (2016) studied the impact of effective and efficient liquidity management on the performance of Nigeria deposit money banks from 2000 to 2010. The relationship between bank performance variables and profitability was examined using some performance indicators such as bank investment, bank deposits, cash ratio and cash reserve requirement as performance indicators. They found a significant relationship between performance variables and profitability which supports some other findings that the survival and sustainability of banks is hinged on the effective and efficient management of its liquidity.

However, there are some identified gaps with respect to the sample size, length of time, and the methodology applied. These identified gap serve as a basis for further empirical investigation, which could assist in understanding the relationship between liquidity indicators and profitability in Nigerian deposit money banks. This study attempted to fill these gaps by extracting data from the annual statements of deposit money banks to empirically investigate the liquidity-profitability nexus.

\section{THEORETICAL FRAMEWORK AND MODEL SPECIFICATION}

Panel data is the outcome of a successive recording of the same individuals in a selected sample for a specific period of time. Even if in the observed sample the criterion for random selection may be very restrictive, eventual correlations may be made among indicators describing individuals over time. The use of panel data in applied research is increasingly gaining relevance both in developed and developing countries partly because of the need to harmonize regional policies and more generally due to the inherent benefits for empirical analyses. Hsiao (2006) provides justification for the consideration of panel data in empirical and policy based studies. These are represented in Baltagi (2008) and summarized.

a. Panel data provide sufficient observations and, consequently, more sample variability, less collinearity, more degrees of freedom, and more accurate inference of model parameters. 
b. Panel data models better capture the complexity of human behaviour than a single cross-section or time series data.

c. Panel data models are better able to capture the heterogeneity inherent in each individual unit. The structure of panel data suggests that the cross-sectional units whether individuals, firms, states or countries are heterogeneous. In empirical modelling, ignoring these heterogeneous effects when in fact they exist leads to biased and inefficient results.

d. The behaviour of economic agents is intrinsically dynamic. These dynamics can neither be captured by cross-sectional framework nor time series models. Cross-sectional models can only ascertain the behavioural pattern at a particular point and therefore cannot be used to capture behavioural dynamics. Similarly, time series data that provides information over a period of time only limits itself to one unit and, therefore, we are unable to compare changes in the behaviour of different economic agents. However, since panel data sets provide time series on each cross-sectional unit in a group, it becomes relatively easy to evaluate the changes in the behavioural pattern.

In specialized literature, panel data also appear under the name of pooled data or longitudinal data (Gujarati, 2004). A panel dataset is a set of cross-section data $Y_{n t}(n=1, \ldots, N$ and $t=1, \ldots, T)$ obtained by means of statistical observation performed periodically in a defined time interval $T$ of variables characteristic for a group of $N$ individuals (Baltagi, 2008). Panel dataset involves a variability of observations for the same individuals over time leading to recording of $N \cdot T$ observations (Hsiao, 2003). From the perspective of this representation, statistical observation shows a variation of individual features contributing to the increase of variability of observations and accuracy of estimation (Sevestre, 2002).

By the size of the sample, panel data may be: balanced (individuals are observed over equal periods of time) or unbalanced (individuals are observed over different periods of time). By the selection method of individuals, panel data set may be classified into: continuous (individuals selected in the sample remain unchanged during recording observations) or rotative (a series of individuals are observed during a number of specified periods, then these may be eliminated from the sample being replaced by other individuals for whom new observations will be recorded)

In what regards the structure of analyzed data, panel data analysis will consider for $N$ individuals, $K$ variables for $T$ different moments. For statistical observation, we may identify three perspectives for panel data analysis: individual $n$, time $t$ and variable $Y$. Based on these notations, $Y_{n t}$ is the observed variable $Y$ for individual $n$ at moment $t$ (Sevestre, 2002). If individuals remain constant, chronological series are obtained and if the period is constant, there will be a sequential series of individuals included in the sample. Depending on the purpose of analysis, panel data set may have more than two dimensions (temporal and individual) by including other factors that will be used to structure the analyzed sample $(N$ individuals over $T$ period for $C$ groups). Some authors argue that in order to make recordings of the panel type, the time variation is not a key criterion if the variation of recorded observations may be explained by at least one dimension ( $N$ individuals observed by $C$ criteria) (Hsiao, 2003).

As shown above, panel data set is characterized by double dimensional representation, temporal and transverse, conferring them a significant advantage compared to other types of data (Sevestre, 2002). 
Temporal dimension enables us to observe individual's evolution over time depending on studied variables. This dimension determines statistical recording of data of each observed statistical unit as time series. For this dimension, the breakdown of total variability in each recorded observation should mainly consider the number periods used in the study. For this case, total variance may be broken down as follows (Sevestre, 2002):

Total variance $=$ Intertemporal variance + Intratemporal variance, or

$$
\sum_{n=1}^{N} \sum_{t=1}^{T}\left(y_{n t}-y_{t}\right)^{2}=N \sum_{t=1}^{T}\left(y_{t}-y_{t}\right)^{2}+\sum_{n=1}^{N} \sum_{t=1}^{T}\left(y_{n t}-y_{t}\right)^{2}
$$

Transversal dimension (individual) allows to observe the variance of features from one individual to another irrespective of period of time $t$ for which observations have been recorded and total variance may be decomposed, as follows (Sevestre, 2002):

Total variance $=$ Inter-individual variance + Intra-individual variance , or

$$
\sum_{n=1}^{N} \sum_{t=1}^{T}\left(y_{n t}-y_{t}\right)^{2}=T \sum_{t=1}^{N}\left(y_{n}-y_{t}\right)^{2}+\sum_{n=1}^{N} \sum_{t=1}^{T}\left(y_{n t}-y_{n}\right)^{2}
$$

By active combining of the two dimensions, total variance of recorded observations may be decomposed, as follows (Sevestre, 2002):

Total variance $=$ Inter-individual variance + Inter-temporal variance + Intra-individual-temporal variance, or

$$
\sum_{n=1}^{N} \sum_{t=1}^{T}\left(y_{n t}-y\right)^{2}=N \sum_{t=1}^{T}\left(y_{t}-y\right)^{2}+T \sum_{t=1}^{N}\left(y_{n}-y\right)^{2}+\sum_{n=1}^{N} \sum_{t=1}^{T}\left(y_{n t}-y_{n}-y_{t}-y\right)^{2}
$$

Main difference between the last breakdown and the first two lies in simultaneous consideration of intra-temporal and intra-individual differences. The breakdown method of total variance as in the last model is the main advantage of studying individuals' behavior from the perspective of the individual and the temporal dimensions (Jaba et al., 2013).

\section{Models of panel data analysis}

To analyze panel data, we start from a series of data recorded for $N$ individuals observed for a $T$ period of time. For these data, the following general model may be written and used for the analysis of a resultative variable $(Y)$ by determinant factors $(X k)$ :

$$
y_{n t}=b_{0 n t}+\sum_{k=1}^{K} b_{k n t} x_{k n t}+w_{n t}
$$

$n=1, \ldots, N$ and $t=1, \ldots, T$, where $y_{n t}$ represents values of dependent variable, $x_{k n t}$, values $K$ for dependant variable, $b_{0 n t}$, a constant and $w_{n t}$, the error component (Sevestre, 2005).

Coefficients $b_{0 n t}$ and $b_{k n t}, k=1, \ldots, K$ varies in time and between individuals. As the behavior of individuals may change in time that regards dependent variables of the studied sample, we may observe in the studied sample the absence of recorded data homogeneity.

As the number of coefficients $(N T(K+1))$ is higher than the total number of observations $(N T)$, it is difficult to estimate the model using traditional methods. In this case, contrasts between coefficients should be used by defining two canonic models: fixed effects models (individual or temporal) and composed error models (random effects). 


\section{Fixed effects models}

In case of fixed effects models, it is assumed that the influence of considered factor variables ( $x_{k n t}$ ) on the dependent variable $\left(y_{n t}\right)$ is identical for all individuals during the entire analyzed period $\left(b_{k n t}=b_{k}\right)$. In this case, the constant $b_{0 n t}$ may be broken down as follows:

$$
b_{0 n t}=b_{0}+a_{n}+d_{t}
$$

where, $b_{0 n t}$ is the constant of the regression model, $b_{0}$, a constant $a_{n}$ indicates unobservable differences between individuals and $d_{t}$ temporal differences that may appear in individuals.

Based on this breakdown, the regression model may be written as follows (Sevestre, 2002):

$$
y_{n t}=b_{0}+a_{n}+d_{t}+\sum_{k=1}^{K} b_{k n t} x_{k n t}+w_{n t}
$$

To estimate parameters of the fixed effects model we may consider the individual and temporal specificity by introducing specific effects also called fixed effects in individuals and temporal periods that represent coefficients to be estimated. In case of a model for a specific period, two companies that have the same observable features should have the same values for the resultative variables:

$$
E\left(y_{n t} / x_{\ln t}, \ldots, x_{k n t}\right)=b_{0}+a_{n}+d_{t}+\sum_{k=1}^{K} b_{k} x_{k n t}
$$

We may observe in this model that if there is a difference in companies stable in time, it may be emphasized by means of the coefficient $a_{n}$. By analogy, the coefficient $d_{t}$ measures the effect of temporal variation of company features.

\section{Random effect models}

In this case, the random character of specific effects differentiates composed effect models from fixed effects models. Generally, composed effect models may be written as (Sevestre, 2002):

$$
y_{n t}=b_{0 n t}+\sum_{k=1}^{K} b_{k n t} x_{k n t}+\varepsilon_{n t}
$$

and,

$$
\varepsilon_{n t}=u_{n}+v_{t}+w_{n t}
$$

where, the specific individual $\left(u_{n}\right)$ and temporal $\left(v_{t}\right)$ effects are random, with zero mean and variance $\sigma_{u}^{2}$ and $\sigma_{v}^{2}$. The model may be easily broken down, the error factor being made up of three elements: a component that does not present autocorrelation $\left(w_{n t}\right)$ neither individually nor temporally, a component as an individual specific effect $\left(u_{n}\right)$ and a component as a temporal specific effect $\left(v_{t}\right)$, not correlated between them or with themselves (Jaba, Chirianu, Balan, Robu, \& Roman, 2016).

Depending on these features, the conditional mean of values $y_{n t}$ are:

$$
E\left(y_{n t} / x_{I \mathrm{n} t}, \ldots, x_{k n t}\right)=b_{0}+\sum_{k=1}^{K} b_{k} x_{k n t}
$$

In case of random effect model, individual effects $u_{n}$ express unobservable personal features and they are uncorrelated with dependent observable variables. 
To choose one of the two types of models (with fixed or random effects), $F$ test and Hausman tests are used (Jaba et al., 2016).

The panel model for this study flows from the theoretical framework on liquidity and profitability relationship. The functional form of the model is given as:

$$
R O A_{i t}=f\left(C T A_{i t}, C T D_{i t}, C T R_{i t} \operatorname{LATA}_{i t} L T D_{i t}\right)
$$

where:

$R O A_{i t}=$ Return on assets of the banks $i$ in period $t$

$C T A_{i t}=$ Cash to total assets of banks $i$ in period $t$

$C T D_{i t}=$ Cash to total deposit for banks $i$ in period $t$

$C T R_{i t}=$ Current Ratio of banks $i$ in period $t$

$L A T A_{i t}=$ Liquid Asset to Total Assets of banks $i$ in period $t$

$L T D_{i t}=$ Loan to Total Deposit of banks $i$ in period $t$

Equation (11) is functional representation which cannot be estimated in its current state. Thus, to make the equation compliant for regression analysis and estimation, the equation is linearly expressed as:

$R O A_{i t}=\alpha_{0}+\alpha_{1} C R T_{i t}+\alpha_{2} C T A_{i t}+\alpha_{3} C T D_{i t}+\alpha_{4} L A T A_{i t}+\alpha_{5} L T D_{i t}+U_{i t}$

Where:

$\alpha_{0}, \alpha_{1}, \alpha_{2}, \alpha_{3}, \alpha_{4}$, and $\alpha_{5}$ represent the values of the variables coefficients

$U_{i t}=$ stochastic or error term.

\section{Apriori expectations of the coefficients of the variables}

$\alpha_{1}>0, \quad \alpha_{2}>0, \quad \alpha_{3}>0, \quad \alpha_{4}>0$, and $\alpha_{5}<0$

The a priori expressions above imply that current ratio, cash to total assets, and liquid asset to total assets and loans to total deposit ratio are all theoretically expected to have a positive effect on return on assets; while cash to total deposits is theoretically expected to have a negative effect on return on assets.

\section{Definition of Terms}

Return on Assets (ROA). The dependent variable chosen for this study is the return on assets (ROA) Ratio. This ratio measures how effectively and efficiently a firm is able to produce income within a given period with it total assets. In other words, ROA ratio is a profitability ratio that measures how well a firm is able to manage its total assets to produce the best results possible in terms of maximizing profit. The formula is given as:

Return on Assets Ratio $=\frac{\text { Net Income }}{\text { Average Total Assets }}$

This ratio can also be called return on investment (ROI), as the term investment may also refer to total assets.

The independent variables (the liquidity management) were measured by the following indicators: 
Current Ratio (CTR). This is a liquidity indicator ratio which measures the banks' ability to meet up with its short-term obligations as they fall due. It measures the banks short term solvency. To measure this ability, current ratio takes into consideration all the liquid and current assets of the bank in relation to the banks current total liabilities. Current ratio is calculated by dividing current assets by current liabilities. It is given as follows:

$$
\text { Current ratio }=\frac{\text { Current assets }}{\text { Current Liabilities }}
$$

The current assets here include cash and all other assets that can be converted to cash within the period of one year. These include debtors and inventories, as well as marketable securities. Prepaid expenses are also included in the current assets as these are considered as expenses that will not be paid for again in the future, as it has been taken care of in the past. Current liabilities on the other hand included bills payable, creditors, short-term bank loan, accrued expenses, long-term debt that is maturing in the current year and income-tax liability. A ratio that is greater than one implies that the bank has more current assets than current claims against them. This ratio is related to liquidity because it is a measure of the banks liquidity.

Cash to Total Assets Ratio (CTA). This ratio is called the cash ratio. The ratio compares the amount of liquid assets to the amount of total liabilities of the bank. Liquid assets such as cash and other marketable securities are considered as liquid assets because they can be easily converted to cash to settle short-term obligations. This ratio is related to liquidity because it shows the liquidity position of the bank and its ability to settle short-term obligations. Since marketable securities are seen as equivalent to cash, they can be included in the computation of cash ratio:

Cash ratio $=\frac{\text { Cash }+ \text { Marketable securities }}{\text { Current Liabilities }}$

The higher the cash ratio, the better the liquidity position of the firm and its ability to meet its day to day financial obligation. However, a ratio of 2:1 or more is considered satisfactory as an outrageous cash ratio will imply excess cash in hand which may not be profitable to the bank. It is advisable that idle cash should be put into profitable investment and a balanced cash ratio should be held by the banks so as to remain profitable and also stay liquid.

Cash to Total Deposit (CTD) Ratio. This ratio also called cash deposit ratio can be defined as the total cash in hand and cash balances with RBI divided by total deposits. It shows the amount a bank lends out to borrowers out of its total deposit; that is; the deposits it has mobilized from the banking public. The cash deposit ratio gives a proper understanding of how much of the bank's deposits is being used for the purpose of lending, which is the main activity of banking.

Cash to total deposit ratio is calculated by dividing total cash and cash balances with total deposit.

Cash Deposit ratio $=\frac{\text { Cash }+ \text { Cash balances }}{\text { Total Deposits }}$

A higher ratio shows that a higher percentage of the total bank deposit is being given out by the bank as loans and grants to the investing public for developmental purposes, which is the main 
banking activity. This ratio is related to profitability because the higher percentage of total deposits is given out as loans, will in turn bring about more profit for the bank instead of keeping idle cash that yields nothing, but on the other hand, indicate a low liquidity power to the bank.

Liquid Assets to total Assets Ratio (LATA). This ratio measures the firm's liquid assets to its total assets. In liquidity crisis, low liquid assets to total assets ratio can be hazardous to a financial institutions health and survival. This ratio is calculated by dividing total liquid assets by total assets. It gives an insight into the liquidity available at the disposal of the bank to settle both the expected and the unexpected cash exigencies. The liquidity level indicates the capability of the bank to withstand shock to their balance sheet. The formula is given as:

Liquid assets ratio $=\frac{\text { Liquid assets }}{\text { Total Assets }}$

The higher this ratio, the stronger the bank is able to settle its current liabilities.

Loan to Total Deposit Ratio (LTD). This is the measure of total loan in relation to total deposits in the same period. When loan to total deposit ratio is high, it indicates low liquidity position by the banks which can affect the bank's ability to grant loans. On the other hand, when the loan to total deposit ratio is low, this indicates a vibrant liquidity status of the bank, which in turn enables the bank to create loans and also invest in other profitable securities. However, this ratio has been flawed as it fails to recognize the maturity and liquidity of banks assets and on the ground that it considers the degree of maturity and liquidity of banks assets to be equal.

\section{EMPIRICAL ANALYSIS AND RESULTS}

This section contains the analyses of data obtained for this study as well as the discussion of results. This section is made up of the descriptive statistics, unit root test, model estimation and interpretation as well as discussion of findings.

\section{Descriptive Statistics}

Table 1 below presents annual mean value, standard deviation, Jarque-bera statistic and probability values of the factors affecting liquidity management and the profitability of deposit money banks in Nigeria.

Table 1: Descriptive Statistics of Variables

\begin{tabular}{|l|c|c|c|c|c|c|}
\hline & $\begin{array}{c}\text { Return on } \\
\text { Assets } \\
\text { (ROA) }\end{array}$ & $\begin{array}{c}\text { Cash to Total } \\
\text { Assets (CTA) }\end{array}$ & $\begin{array}{c}\text { Cash to Total } \\
\text { Deposit (CTD) }\end{array}$ & $\begin{array}{c}\text { Current Ratio } \\
\text { (CRT) }\end{array}$ & $\begin{array}{c}\text { Liquid Asset to } \\
\text { Total Assets } \\
\text { (LATA) }\end{array}$ & $\begin{array}{c}\text { Loan to Total } \\
\text { Deposit (LTD) }\end{array}$ \\
\hline Mean & 0.827758 & 0.146250 & 0.273440 & 1.213332 & 1.673145 & 0.702230 \\
\hline Median & 1.405079 & 0.127629 & 0.180321 & 1.027373 & 1.397810 & 0.549697 \\
\hline Maximum & 9.536409 & 0.591020 & 6.975889 & 9.209206 & 31.26639 & 13.80014 \\
\hline Minimum & -29.64348 & 0.016487 & 0.024432 & -0.164657 & 0.895124 & 0.144112 \\
\hline Std. Dev. & 4.354214 & 0.109713 & 0.665981 & 1.604722 & 2.860281 & 1.273842 \\
\hline Jarque-Bera & 3181.582 & 133.0877 & 40417.49 & 521.8084 & 50619.97 & 48120.49 \\
\hline Probability & 0.000000 & 0.000000 & 0.000000 & 0.000000 & 0.000000 & 0.000000 \\
\hline Observations & 110 & 110 & 110 & 110 & 110 & 110 \\
\hline
\end{tabular}

Source: Authors' Computation (2018)

The result above shows that the average liquidity ratio for the selected banks in Nigeria is $0.828 \%$ for the sampled period. The sector also has maximum and minimum liquidity ratio of 
9.54\% and $-29.64 \%$ respectively for the sampled period. In terms of the level of variability as revealed by standard deviation (4.35) of the liquidity ratio, the selected deposit money banks' have a higher standard deviation as related to the mean ratio over the period. The descriptive statistics for the explanatory variables also shows that the selected banks' liquid assets to total assets seems to be the most volatile variable in the set, since it possesses the highest standard deviation value among the explanatory variables. This is followed by current ratio and loan to total deposit ratio with standard deviation value of 1.605 and 1.274 respectively, thereafter, cash to total deposit ratio and cash to total assets ratio with standard deviation values of 0.666 and 0.11 respectively.

All the variables in the series are normally distributed at $\mathrm{P}<0.1$ which support the use of panel data modeling approach.

\section{Unit Root Test}

Unit root test generally involves the stationarity test for variables used in regression analysis. The starting point of an empirical analysis is to examine the stationarity properties of the time series. This is important because a non-stationary series can lead to bias and misleading inferences. This study used Levin, Lin and Chu unit root test to ascertain the stationarity of the variables. Levin, Lin and Chu (2002) unit root test is used because they established the foundation for panel unit root test (Nam \& Robert, n.d).

Table 2: Unit Root Test

\begin{tabular}{|l|c|c|c|c|}
\hline \multicolumn{1}{|c|}{ Variables } & Statistic & Prob. & Integration & Remark \\
\hline Return on Asset (ROA) & -2.04865 & 0.0202 & I [0] & Stationary \\
\hline $\begin{array}{l}\text { Current Ratio (current assets to current } \\
\text { liabilities) (CRT) }\end{array}$ & -6.24249 & 0.0000 & I [0] & Stationary \\
\hline Cash to Total Assets (CTA) & -13.3148 & 0.0000 & I [0] & Stationary \\
\hline Cash to Total Deposit (CTD) & -14.4559 & 0.0000 & I [0] & Stationary \\
\hline Liquid asset to total assets (LATA) & -1.34440 & 0.0894 & I [0] & Stationary \\
\hline Loan to total deposit (LTD) & -29.8307 & 0.0000 & I [0] & Stationary \\
\hline
\end{tabular}

Source: Authors' Computation (2018)

The results revealed that all the variables are stationary at levels at $5 \%$ level of significance. It can be conclusively stated that the variables do not possess unit roots are integrated of order 0 (I[0]) as shown in table 2 above.

\section{Model Estimation and Interpretation}

This section contains three forms of estimations: Pooled ordinary least squares (Pooled OLS, fixed effect model (FEM), and random effect model (REM) carried out in this study. Also Hausman cross-sectional test was conducted to know the most appropriate model to use. 
Table 3: Results of Estimated Models

\begin{tabular}{|c|c|c|c|}
\hline \multicolumn{4}{|c|}{$\frac{\text { Dependent Variable: ROA }}{\text { Variable }}$} \\
\hline Variable & Pooled OLS & Fixed Effect Model & Random Effect Model \\
\hline \multirow[t]{2}{*}{$\mathrm{C}$} & $\begin{array}{c}-8.66 \\
(-2.48)\end{array}$ & $\begin{array}{c}-8.27 \\
(-2.29)\end{array}$ & $\begin{array}{c}-8.54 \\
(-2.45)\end{array}$ \\
\hline & {$[0.01]$} & {$[0.02]$} & {$[0.02]$} \\
\hline \multirow[t]{3}{*}{ CRT } & 0.28 & 0.14 & 0.23 \\
\hline & $(1.06)$ & $(0.47)$ & $(0.88)$ \\
\hline & [0.29] & {$[0.64]$} & {$[0.38]$} \\
\hline \multirow[t]{3}{*}{ CTA } & 44.91 & 42.48 & 44.15 \\
\hline & (2.73) & $(2.48)$ & $(2.70)$ \\
\hline & {$[0.01]$} & {$[0.01]$} & [0.008] \\
\hline \multirow[t]{3}{*}{ CTD } & -26.70 & -27.78 & -27.08 \\
\hline & $(-2.48)$ & $(-2.50)$ & $(2.53)$ \\
\hline & [0.01] & {$[0.01]$} & {$[0.01]$} \\
\hline \multirow[t]{3}{*}{ LATA } & 4.44 & 5.65 & 4.82 \\
\hline & (1.92) & $(-2.50)$ & (2.09) \\
\hline & {$[0.06]$} & {$[0.02]$} & {$[0.04]$} \\
\hline \multirow[t]{3}{*}{ LTD } & 3.50 & 1.22 & 2.79 \\
\hline & $(1.51)$ & $(0.48)$ & (1.18) \\
\hline & {$[0.14]$} & [0.65] & {$[0.24]$} \\
\hline R-squared & 0.58 & 0.52 & 0.57 \\
\hline Adjusted R-squared & 0.53 & 0.50 & 0.53 \\
\hline F-statistic & 11.84 & 11.77 & 11.59 \\
\hline Prob(F-statistic) & 0.00 & 0.00 & 0.00 \\
\hline Durbin-Watson stat & 2.24 & 2.38 & 2.34 \\
\hline Observations & 110 & 110 & 110 \\
\hline \multicolumn{4}{|c|}{ Hausman Cross-Sectional Test } \\
\hline Test Summary & Chi-sq Stat & Chi-Sq. d.f & Prob. \\
\hline Cross-Section Random & 5.68 & 5 & 0.34 \\
\hline
\end{tabular}

Note: t-statistics and probability values are in bracket 0 and parenthesis [ ] respectively. The estimated model is shown below:

Table 3 presents the results of pooled ordinary least squares model, fixed effect model, and random effect model. A total of six (6) variables were used in the estimation. Return on asset ROA) was used as the dependent variable while current ratio (CRT), cash to total assets (CTA), cash to total deposit (CTD), liquid asset to total assets (LATA), and loan to total deposits (LTD) were used as the independent variables. From the pooled OLS, the results show that cash to total assets (CTA), cash to total deposits (CTD), and liquid assets to total assets (LATA) are significant at $1 \%, 1 \%$ and $10 \%$ respectively. Whereas cash to total assets (CTA) and liquid asset to total assets (LATA) have a positive relationship with return on assets (ROA), cash to total deposits (CTD) has a negative relationship with return on assets (ROA). The $R$-Squared is 0.58 showing that the explanatory variables explain $58 \%$ of the changes in the dependent variable.

The fixed effect model (FEM) results show that cash to total assets (CTA), cash to total deposits (CTD), and liquid assets to total assets (LATA) are significant at 1\%,1\% and 10\% respectively. Whereas cash to total assets (CTA) and liquid assets to total assets (LATA) have a positive relationship with return on assets (ROA), cash to total deposits (CTD) has a negative relationship with return on assets (ROA). The $R$-Squared is 0.52 showing that the explanatory variables explain $52 \%$ of the changes in the dependent variable. 
The random effect model (REM) results show that cash to total assets (CTA), cash to total deposits (CTD), and liquid assets to total assets (LATA) are significant at 1\%, 1\% and 5\% respectively. Whereas cash to total assets (CTA) and liquid assets to total assets (LATA) have a positive relationship with return on assets (ROA), cash to total deposits (CTD) has a negative relationship with return on assets (ROA). The $R$-Squared is 0.57 showing that the explanatory variables explain $57 \%$ of the changes in the dependent variable.

The $F$-statistics which measure the overall statistical significance of the models show that the models are statistically significant at $1 \%$ level $(\mathrm{F}$-value $=11.84, \mathrm{p}$-value $=0.000$ for pooled OLS; F-value $=11.77, \mathrm{p}$-value $=0.000$ for fixed effect model; and F-value $=11.59, \mathrm{p}$-value $=$ 0.000 for random effect model). The Durbin-Watson Statistics of 2.24, 2.38, and 2.34 for pooled OLS, fixed effect and random effect models show the absence of autocorrelation in the models.

In selecting the best model to use for analysis, the Hausman cross-sectional test was conducted. The result in Table 3 shows that the $p$-value for the test is greater than $5 \%$, indicating that the random effects model was more appropriate and preferred. Therefore, the random effect specification results are interpreted and used for this study.

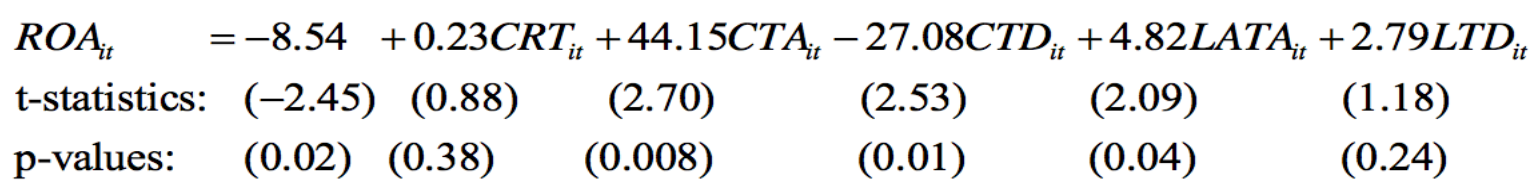

DISCUSSION OF FINDINGS

This study empirically investigated the effects of liquidity management on the profitability of deposit money banks in Nigeria from 2006 to 2016, using the panel ordinary least squares regression method. Data used for the study were sourced from the annual reports of the sampled firms and the statistical bulletin of the Central Bank of Nigeria.

The regression results showed that cash to total assets ratio (CTA), cash to total deposit (CTD), and liquid assets to total assets (LATA) are statistically significant in explaining the behavior of profitability in the deposit money banks in Nigeria while current ratio (CRT) and liquid assets to total assets (LATA) are not. This means that cash to total assets ratio (CTA), cash to total deposit (CTD, and liquid assets to total assets (LATA) are significant indicators which tend to predict the behavior of profitability in the deposit money banks in Nigeria.

Since the regressors are in percentages, $1 \%$ increase in cash to total assets ratio (CTA) leads to a significant increase in profitability in the deposit money banks in Nigeria by $44.91 \%$ on the average. In the same vein, $1 \%$ increase in liquid assets to total assets (LATA) leads to a significant increase in profitability in the deposit money banks in Nigeria by $4.44 \%$ on the average. That liquidity ratio has positive effect on banks profitability is in agreement with the findings by Bourke (1989) that liquidity ratio has a positive and significant effect on banks profitability.

Conversely, 1\% increase in cash to total deposit (CTD) leads to a significant decrease in profitability in the deposit money banks in Nigeria by $26.7 \%$ on the average. This finding is in line with the theory of (Aghada \& Osuji, 2013) and it is also supported by the a priori expectation of this study. The findings of a negative relationship between cash to total deposit and profitability of deposit money banks in Nigeria by Bassey and Moses (2015) also support the findings of this study. 
This study also found a positive and non-significant relationship between current ratio (current assets to current liabilities) and deposit money banks profitability in Nigeria. this finding is not consistent with the finding of Maqsood et al (2016) that current ratio has a positive and significant relationship with banks' profitability contradicts this finding.

Finally, it was found that loan to total deposit (LTD) ratio has a positive but insignificant relationship with the profitability of deposit money banks in Nigeria. This finding supports the findings of Bassey and Moses (2015) that found that loan to deposit ratio had an insignificant effect on the return on assets (ROA) of the deposit money banks in Nigeria.

\section{CONCLUSION AND POLICY RECOMMENDATIONS}

This study empirically investigated the liquidity indicators or measures that influence the profitability of deposit money banks in Nigeria from 2006 to 2016. The study combined both cross-sectional and time series data (panel data) on the selected variables (return on assets, current ratio, cash to total assets, cash to total deposits, liquid assets to total assets, and loan to total assets. The selected random effect model based on the Hausman test indicate that that cash to total assets ratio (CTA), cash to total deposit (CTD), and liquid assets to total assets (LATA) are statistically significant in explaining the behavior of profitability in the deposit money banks in Nigeria while current ratio (CRT) and liquid assets to total assets (LATA) are not. All the parameters are consistent with theoretical expectations. The relationship between cash to total assets ratio (CTA), cash to total deposit (CTD), liquid assets to total assets (LATA) and profitability in the deposit money banks in Nigeria were positive, negative, and positive respectively.

Banks viability could be linked directly to the management of their liquidity. The banks should therefore set among their priorities the ability to meet up with their day to day financial obligations. Therefore, deposit mobilization should be among the vital functions of the banks. This will give the banks enablement to mobilize unproductive and idle deposits to the deficit sector in the economy. The continuous interest paid by borrowers on their loan will also ensure the provision of productive resources at all time. The banks liquidity should be managed in such a level that they can maximize revenue by managing liquidity while the risk of insolvency is held at a reasonable level.

Following the analyses and findings of this study, the following are recommended:

1. The deposit money banks should consider cash to total assets ratio (CTA) variable if the objective is to increase profitability drastically and consider liquid assets to total assets (LATA) variable if the objective is to increase profitability gradually; and the deposit money banks should consider the cash to total deposits (CTD) factor if the objective is to reduce profitability.

2. The deposit money banks should not only focus on the profit maximization perception but also embrace methods that will provide effective and efficient liquidity management since their survival and sustainability depend on liquidity management and profitability. This will help to reduces incidence of deficient and excessive liquidity as their effects are adverse.

3. The deposit money banks in Nigeria should as much as possible try to work out a good portfolio mix which can be achieved by analyzing and studying the situation and choosing a balanced and diversified portfolio mix that will ensure the survival, stability, as well as the growth and development of the banking industry in Nigeria.

4. The monetary authorities through the central bank of Nigeria should as much as possible try to maintain an adjustable lending rate that will enable the banks to take 
advantage of the various means of meeting unexpected withdrawal obligations to customers, thereby reducing the instances of holding idle cash which is of no benefit to the banks.

\section{References}

Adenikinju, A., Busari, D. \& Olofin, S. (2009). Applied econometrics and macroeconometric modeling in Nigeria. Ibadan: Ibadan University Press.

Adeyinka, S. (2013). Capital adequacy and banks' profitability: An empirical evidence from Nigeria. American International Journal of Contemporary Research, 3 (10), 122 - 137.

Aghada, A.O. \& Osuji, C. C. (2013). The efficacy of liquidity management and banking performance in Nigeria. International Review of Management and Business Research, 2 (1), 94 - 112.

Allen, F. E. \& Marquez, H. (2011). Credit market competition and capital regulation. Review of Financial Studies 24, 214-239

Arinze, A.C. (2012). Foreign exchange reserves in Asia and its impacts on import demand. International Journal of Economics and Finance, 4 (3), 55-68.

Baltagi, B.H. (2008). Econometric analysis of panel data, 4th edition. West Sussex: John Wiley \& Sons.

Bassey, G. E. (2016). The impact of recapitalization and consolidation on bank performance in Nigeria, International Journal of African Culture, Politics and Development, 7 (2), 81- 99.

Bassey, G. E. \& Moses, C.E. (2015). Bank profitability and liquidity management: A case study of selected Nigerian deposit money banks. International Journal of Economics, Commerce and Management (UK), III (4), 1 - 24.

Biety, M. (2003). Liquidity and asset liability management in saving services for the poor: An operational guide. Washington D.C.: Pact Publication.

Bordeleau, E. \& Graham, C. (2010). The impact of liquidity on bank profitability. Bank of Canada Working Paper/Document No. 38.

Bourke, P. (1989). Concentration and other determinants of bank profitability in Europe, North America and Australia. Journal of Banking and Finance, 13, 65 - 79.

Brancato, C.K. (1995). New performance measures. New York: Conference Board.

Central Bank of Nigeria: Statistical Bulletin (Various Editions), Abuja.

Eljelly, A. (2004). Liquidity-profitability trade-off: An empirical investigation in an emerging market. International Journal of Commerce and Management, 14 (2), 34-49.

Fadare, S. (2011). Banking crisis and financial stability in Nigeria. International Research Journal of Finance and Economics, ISSN 1450-2887 Issue 63

Fernandez, F. A. (1999). Liquidity risk: New approaches to measurement and monitoring. Securities Industry Association Working Paper.

Flannery, M. J. \& Regan, P. (2008). What caused the bank capital build-up of the 1990s? Review of Finance 12.

Goddard, J., Molyneux, P. \& Wilson, J. O. S. (2004). Dynamics of growth and profitability in banking. Journal of Money, Credit and Banking, 36, 102-130.

Gurajati, D. (2004). Basic econometrics. 4th Edition. New York: McGraw-Hill.

Hsiao, C. (2006). Analysis of panel data. Cambridge: Cambridge University Press.

Ibe, S. O. (2013). The impact of liquidity management on the profitability of banks in Nigeria. Journal of Finance and Banking Management, 1(1), 37-48. Retrieved from http://www.aripd.org/jfbm

Ismail, R. (2016). Impact of liquidity management on profitability of Pakistani Firms, International Journal of Innovation and Applied Studies, 14, 304-314. Retrieved march 2017, from ://www.ijias.issr-journals.org/

Jaba, E., Chirianu, I.A., Balan, C.B., Robu, I.B. \& Roman, M. (2016). The analysis of the effect of women's participation in the labor market on fertility in European Union countries using welfare state models. Economic Computation and Economic Cybernetics Studies and Research, 50 (1), 69-84

Jaba, E., Mironiuc, M., Roman, M., Robu, I.B. \& Robu, M.A. (2013). The statistical assessment of an emerging capital market using the panel data analysis of the financial information. Economic Computation and Economic Cybernetics Studies and Research, 47 (2), 21-36 
Maqsood, T., Anwer, M.A., Raza, A., Ijaz, M. \& Shouqat, U. (2016). Impact of liquidity management on profitability in banking sector of Pakistan. International Review of Management and Business Research, 5 (2), 43 - 64.

Naceur, S. (2003). The determinants of the Tunisian banking industry profitability: Panel evidence. Paper presented at the Proceedings of the Economic Research Forum (ERF) 10th Annual Conference, Marrakesh-Marocco.

Oriavwote, E.V. \& Eshenake, S. (2015). Does fiscal policy matter for economic growth? An empirical assessment of the Nigerian situation. International Journal of Business and Social Sciences, 6 (11), 77 - 84.

Osborn, M., Fuertes, A. \& Milne, A. (2012). Capital and profitability in banking: Evidence from US Banks. https/ miller bank profitability.

Sevestre, P. (2002). Économetrie des données de panel. Paris: Dunod

Shaibu, I. (2010). Strategic management: Theory and cases. Benin City: Acme Publishers.

Wilner, B. (2000). Competitive conditions in European banking, Journal of Banking and Finance, 18. 